\title{
SYNTHESIS AND CHARACTERIZATION OF INDIGENOUS HYDROPHILIZED POLYVINYLIDENE FLUORIDE MEMBRANE FOR DRINKING WATER PURIFICATION: EXPERIMENTAL STUDY AND MODELING ASPECTS
}

\author{
Kancharla Ravichand1, Vadeghar Ramesh Kumar', Ginuga Prabhakar Reddy', \\ Sundergopal Sridhar ${ }^{2,}$
}

https://doi.org/10.23939/chcht14.02.239

\begin{abstract}
Indigenous polyvinylidene fluoride (PVDF) membrane was hydrophilized by blending with polyvinyl alcohol (PVA) which was further cross-linked with glutaraldehyde and tested for surface water purification. Synthesized membranes were characterized by SEM and FTIR to study the surface and cross-sectional morphologies and intermolecular interactions, respectively. The effect of parameters, namely feed pressure, operational time, and the cross-linking agent concentration on the process efficiency was studied. PVDF/PVA blend membrane exhibited a reasonable process flux of $205 \mathrm{l} / \mathrm{m}^{2} \cdot \mathrm{h}$ at $0.5 \mathrm{MPa}$ and ambient temperature of $308 \mathrm{~K}$. Experimental data were fitted to the limiting flux, osmotic pressure and pore blocking model to find the suitable theoretical model to predict the effect of concentration polarization on the separation performance and back flushing frequency. Osmotic pressure model was found to be a suitable model and the predicted results from the model were in agreement with the experimental findings. After the model was validated for the synthesized membrane, the simulation was carried out to predict the cake formation and the back flushing time was found as $97 \mathrm{~h}$. Cost estimation was carried out for a pilot plant of capacity of $1000 \mathrm{~m}^{3} /$ day to emphasize the economic feasibility of the developed process.
\end{abstract}

Keywords: hydrophilized polyvinylidene fluoride, ultrafiltration, turbidity, glutaradehyde, cross-linking, polyvinyl alcohol.

\section{Introduction}

The conventional pre-treatment disinfection/ flocculation/coagulation/multimedia filtration is widely

\footnotetext{
${ }^{1}$ University College of Technology (UCT), Osmania University, Hyderabad 500007, India

${ }^{2}$ Membrane Separations Group, Chemical Engineering Division, CSIR-Indian Institute of Chemical Technology (CSIR-IICT), Hyderabad 500007, India

sridhar11in@yahoo.com

(c) Ravichand K., Kumar V., Reddy G., Sridhar S., 2020
}

applied for water treatment and removal of suspended solids and turbidity. This process does not remove suspended particles and colloids completely and also feed water quality and quantity will fluctuate due to unsteady behaviour. As a result, lower permeate flux and recovery values are considered while designing for stable long-term performance. Ultrafiltration (UF) processes consistently produce good quality water at low-pressure with the higher reliability and better economics by reducing turbidity and suspended solids, and remove bacteria [1-2]. However, the UF element has severe membrane fouling characteristics and plugging of fibers, not preferred method in treating highly fouling surface water as their flux rates are lower. This demonstrates the need for the membranes that are hydrophilic with better fouling resistance.

In recent years, polymeric membranes, especially polyvinylidene fluoride (PVDF) membrane was typically regarded as a polymeric material with outstanding characteristics, e.g., being corrosion-resistant, acid-proof, alkali-proof, and having excellent mechanical properties. Several studies have shown that ultrafiltration (UF) is one of the most effective pre-treatment techniques for the treatment of industrial/municipal wastewater [3-5]. These membranes are widely used in the surface water purification and industrial effluent treatment. Commercially available hydrophilized membranes are mostly produced by the addition of hydrophilic polymers such as polyvinylpyrrolidone (PVP) or polyethylene glycol (PEG) into the casting solution. The main methods used to modify the porous membranes are based on coating technique (hydrophilic layer such as polyvinyl siloxane, polyethylene amine, polyacrolein and hydroxyethyl cellulose), grafting polymerization (grafting of monomers like vinyl acetate, sodium styrene sulfonates and 2-hydroxyethyl methacrylate), in situ copolymerization (two different monomers with the second monomer as a cross-linker to offer mechanical strength (3,4-ethylenedioxy- $N$-methylamphetamine, divinylbenzene (DVB), methylene bisacrylamide)) and other methods such as cocasting of hydrophobic and hydrophilic polymer. Liu et al. 
[6] reviewed the progress on PVDF membrane synthesis and the modifications performed to make hydrophilic membranes capable either of surface modification or blending. Common doping agents studied by various authors are polyvinyl alcohol (PVA) [7], mixed solutions of polyethyleneimine (PEI) and $p$-xylene dichloride (XDC), PVA and poly(acrylic acid-co-maleic acid) (PAM) [8], composite of polyethylene glycol(PEG), polyvinyl alcohol (PVA) and glutaraldehyde [9-10]. Polyvinyl alcohol is a polymer miscible with PVDF, which has a high degree of intermolecular interaction between PVA and PVDF chains [9, 11]. PVDF membranes have been blended with hydrophilic PVA due to the strong polarity of hydroxyl groups present in PVA. Hydrophilic behaviour of the synthesized PVDF ultrafiltration membranes have been enhanced due to the formation of hydrogen bonds with water molecules. Zhang et al. [12] used PVA as UF membrane material and controlled its hydrophilicity; the membrane could effectively reduce protein fouling. PVDF-based PVA and nanocomposite membranes were developed using surfacemodified $\mathrm{TiO}_{2}$ nanoparticles for enhancing antifouling properties [13-14, 27]; the reported flux and \% rejection were found to be in the range of $20-200 \mathrm{l} / \mathrm{m}^{2} \cdot \mathrm{h}$ and 30 $80 \%$, respectively. However, it was observed that the increase of nano- $\mathrm{TiO}_{2}$ concentration within the membrane matrix resulted in the decline of the membrane flux. Recently, Jun $\mathrm{Xu}$ [15] performed pilot plant studies on hydrophilic PVDF membrane and the average flux and rejection of TSS were found to be $751 / \mathrm{m}^{2} \cdot \mathrm{h}$ and $100 \%$. Moreover, consistency of process flux with time indicates good anti-fouling properties of the synthesized membranes.

In this present study, a glutaraldehyde crosslinked PVA/PVDF membrane was synthesized and used for drinking water purification. Synthesized membranes were characterized by SEM and FTIR to study the surface and cross-sectional morphologies and intermolecular interactions. Flux and turbidity rejection studies were performed for surface water at a laboratory scale skid mounted ultrafiltration unit with the variation of operating parameters such as membrane composition (with varying cross-linker percentage), feed pressure and operational time. Theoretical models such as a limiting flux, osmotic pressure and pore blocking models were verified for the experimental results. Osmotic pressure model was found to be the most appropriate for the prediction of the process flux and efficiency. Detailed cost estimation for a pilot ultrafiltration plant of $1000 \mathrm{~m}^{3} /$ day capacity was also estimated for understanding the economic feasibility of the process on a commercial scale.

\section{Experimental}

\subsection{Materials}

PVDF was procured from Akanksha Enterprises, Pune, India, PVA and polyester fabric from Permeonics membranes Pvt Ltd, Vadodara, India, while $N, N$ dimethylformamide (DMF) was purchased locally from sd Fine Chemicals, Hyderabad, India and used without further purification. Cross-linking agent glutaraldehyde was purchased from Finar Chemicals limited, Ahmedabad, India. Demineralized water was generated using a double stage laboratory reverse osmosis unit. Feed water consisted of $4130 \mathrm{ppm}$ total dissolved solids (TDS), $7.6 \mathrm{mS} / \mathrm{cm}$ conductivity, 230 FAU of turbidity and $\mathrm{pH} 6.5$.

\subsection{Membrane Synthesis}

$15 \mathrm{wt} \%$ homogeneous PVDF polymer solution was prepared by adding $15 \mathrm{~g}$ of PVDF polymer in $85 \mathrm{ml}$ of dimethylformamide (DMF) solvent. To this solution, different amounts of PVA polymer along with $2 \mathrm{ml}$ of glutaraldehyde $(\mathrm{GA})$ as a cross-linker were added in concentrations of 10 and $15 \mathrm{wt} \%$ of PVDF weight and the solution was kept under stirring for $4 \mathrm{~h}$ at $358 \mathrm{~K}$. The obtained solution was made bubble-free and cast on a macroporous, nonwoven polyester fabric. The thickness of the membrane was adjusted by controlling the gap between the casting knife (doctor's blade) and glass plate (Fig. 1). Immediately after the solution casting, the plate along with the nonwoven backing was immersed in a solvent-free ice-cold water bath and kept for $1 \mathrm{~h}$ to obtain a porous membrane by a phase inversion method. Three hydrophilic PVDF membranes, namely M-1, M-2, and M-3 were synthesized in this study. Details of the synthesized membrane compositions are provided in Table 1 . Membranes were stored in $0.1 \%$ sodium metabisulfite solution to prevent bio-fouling.

The formation conditions were repeatable as seen from subsequent results presented on characterization (Section 3.1) and separation performance (Section 3). A composition of $2.25 \% \mathrm{PVA}$ and $2 \%$ glutaraldehyde in $15 \%$ PVDF solution using DMF solvent was found to give optimum performance.

Table 1

The composition of the synthesized PVA/PVDF blend membranes

\begin{tabular}{|c|c|c|c|}
\hline Membrane prepared & Polymer Solution & PVA, \% & Glutaraldehyde, \% \\
\hline M-1 & $15 \mathrm{wt} \%$ PVDF in DMF & 1.5 & 2 \\
\hline M-2 & $15 \mathrm{wt} \%$ PVDF in DMF & 1.5 & 0 \\
\hline M-3 & $15 \mathrm{wt} \%$ PVDF in DMF & 2.25 & 2 \\
\hline
\end{tabular}



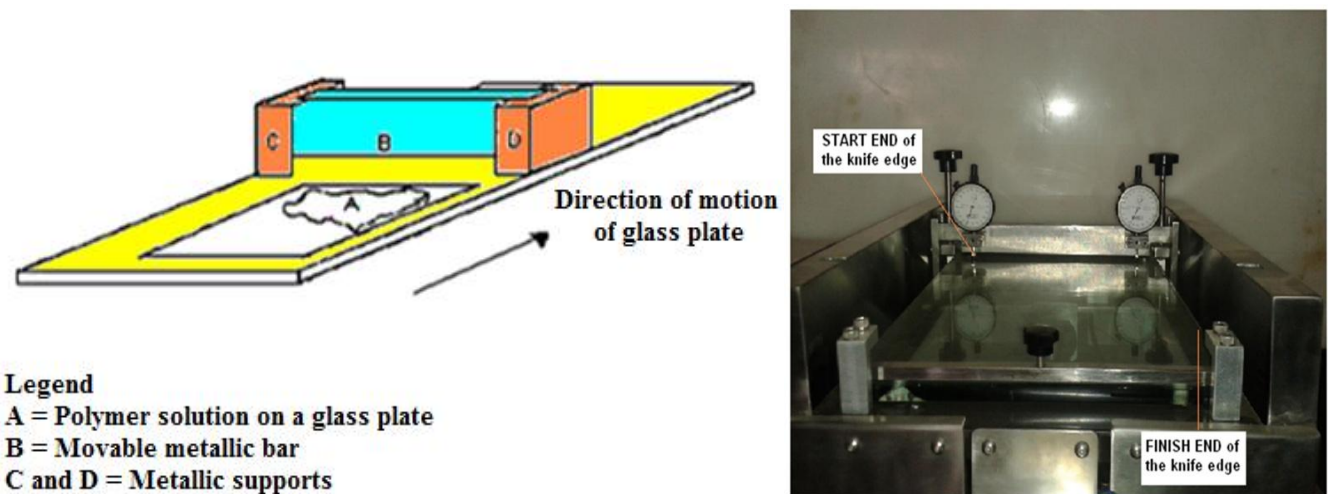

Fig. 1. Schematic membrane casting unit

Legend

$A=$ Polymer solution on a glass plate

$\mathrm{B}=$ Movable metallic bar

$\mathrm{C}$ and $\mathrm{D}=$ Metallic supports

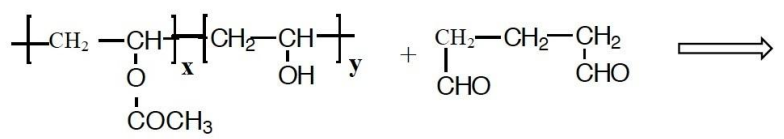<smiles>CCC(C)OC(O)CCCC1OC(CC)CC(CC)O1</smiles>

Polyvinyl Alcohol Chains crosslinking

(a)

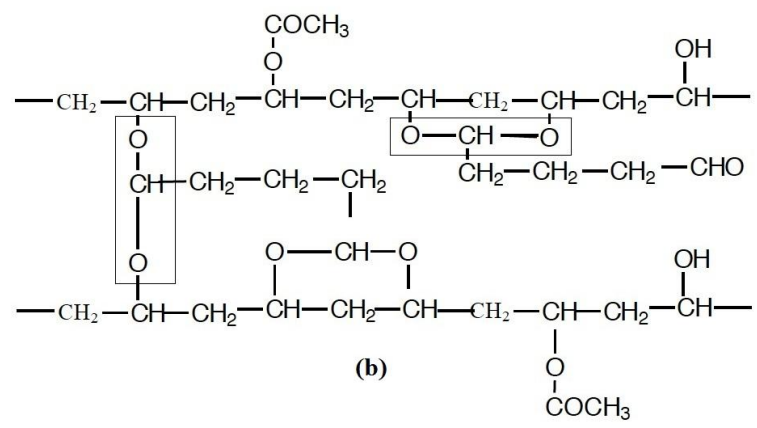<smiles>CCC(O)CC(O)CC(O)CC(O)CC(C)O</smiles>

Fig. 2. Structural transformations in membrane: inter-molecular cross-linking (a); intra-molecular cross-linking (b), and acetal formation (c)

\subsection{Membrane Structural}

\section{Characterization}

Fig. 2 explains the inter-molecular and intramolecular interactions due to the cross-linking of glutaraldehyde in the prepared PVA/PVDF blend membranes. PVA interaction with the glutaraldehyde leading to the acetal formation was also described in the figure in addition to the inter-molecular interactions of glutaraldehyde and intra-molecular interactions between PVA and glutaraldehyde.

\subsection{Membrane Characterization}

Scanning electron microscope (JeOL JSM-5410, LA, USA) was used to study the membrane surface and cross-sectional morphologies. In preparing the specimens, 
the fracture surface and cross-section of the active PVDF membrane layer, and nonwoven polyester fabric support were obtained by cutting the membrane after dipping into liquid nitrogen to ensure smooth morphology.

The synthesized membranes were characterized for intermolecular interactions by scanning in the IR spectrum range of $400-4000 \mathrm{~cm}^{-1}$ wave number using Thermo Nicolet Nexus Nicolet-740 (resolution: $4 \mathrm{~cm}^{-1}$ ), PerkinElmer-283B FTIR spectrophotometer (Boston, MA, USA) by $\mathrm{kBr}$ pellet method.

\subsection{Experimental Procedure}

\subsubsection{Description of the ultrafiltration system}

Fig. 3 shows the schematic diagram of the UF system used for studying the flux and turbidity removal characteristics. A stainless steel tank of 11 capacity was used to feed the UF system. A polytetrafluoroethylene (PTFE) prefilter cartridge of $0.2 \mu \mathrm{m}$ pore size was installed upstream of the membrane module to prevent the entry of suspended solid particles. A high-pressure $2 \mathrm{HP}$ single phase motor driven pump (Hironisha, Japan) capable to provide $1 \mathrm{MPa}$ pressure was installed for pumping the feed to a membrane module. The flat sheet membrane test cell consisted of rectangular chambers clamped together with external flanges by means of tierods to give a tight arrangement. The top half was used as the feed chamber and the bottom half worked as a permeate chamber. The membrane was supported on a stainless steel porous plate, which was embedded with a stainless steel 316 mesh. The effective area of the membrane used is $0.002 \mathrm{~m}^{2}$. A needle valve was used to maintain desired pressure on the concentrate outlet of the membrane pressure vessel. Pressure gauge was installed on the concentrate outlet of the membrane. Permeate and concentrate flow rates were measured using rotameters. Turbidity values of the feed, permeate and reject samples were measured using DR/890 colorimeter (Hach USA). Conductivity and $\mathrm{pH}$ were measured using a digital conductivity meter (DCM-900) and pH meter (DPH-504), purchased from Global Electronics, Hyderabad, India.

\subsubsection{Pure water flux}

At the beginning of experiments, the system was washed with deionised water until the permeate conductivity reached $0.01 \mathrm{mS} / \mathrm{cm}$. Then experiments were performed to find the pure water flux at different pressures. Flux is calculated using Eq. (1):

$$
J=\frac{V}{A \cdot t}
$$

where $V$ is the permeate volume collected, $\mathrm{L} ; A$ is the membrane area, $\mathrm{m}^{2}$; and $t$ is time, $\mathrm{h}$.

\subsection{Theoretical Models to Predict Mass Transfer in UF}

\subsubsection{Limiting flux model with a constant mass transfer coefficient}

Concentration polarisation is the phenomenon whereby there is a gradient in the concentration from a membrane wall to the bulk concentration. As indicated in Fig. 4 , the solute concentration is at its highest $\left(C_{m}\right)$ and lowest $\left(C_{b}\right)$ values at the wall and in the bulk solution, respectively [20-22]. Solute balance in the region to the left of the dashed line gives Eq. (2):

$$
J C_{p}-J C_{b}-\left(-D \frac{d C}{d x}\right)=0
$$

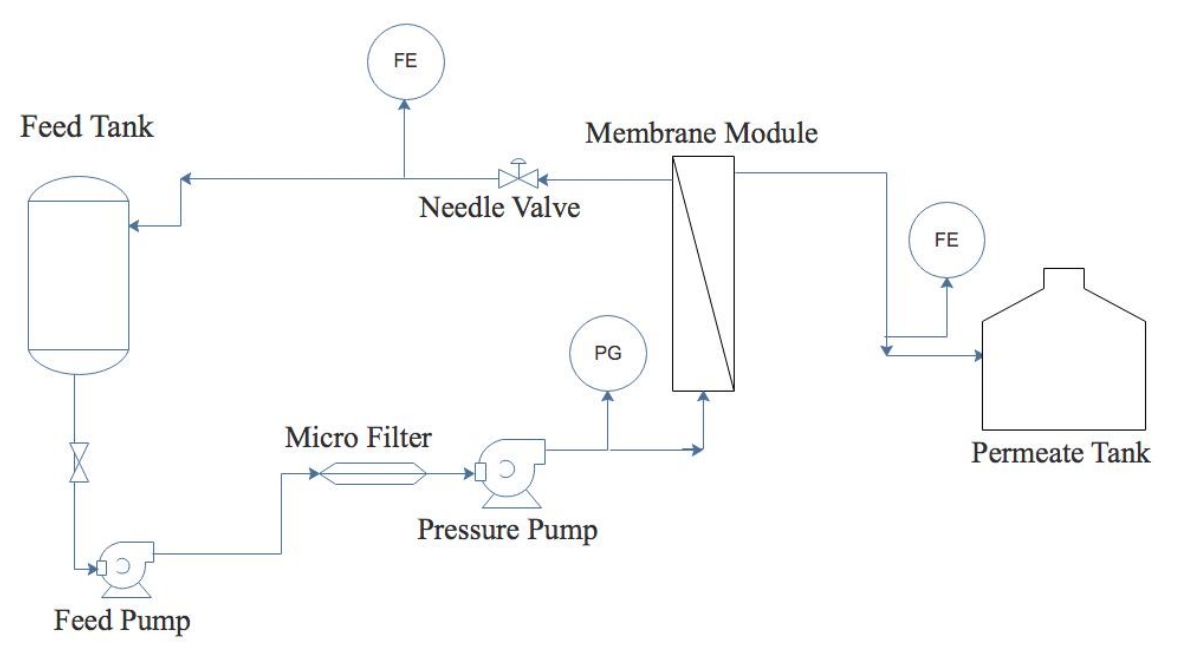

Fig. 3. Schematic representation of the bench-scale ultrafiltration setup 
Integrating Eq. (2) over the film thickness and assuming complete rejection of the solute, the model is governed by Eq. (3):

$$
J_{\lim }=k \ln C_{\lim }-k \ln C
$$

where the tendency of wall concentration to reach an apparently limiting value is represented by $C_{\text {lim. }}$.

\subsubsection{Limiting flux model with a viscosity dependent mass transfer coefficient}

It is a non-linear model with the viscosity dependency and the governing Eq. (4) is shown below:

$$
J_{\lim }=k_{0} \cdot e^{0.14 \gamma\left(C-C_{\lim }\right)} \cdot \frac{\ln C_{\lim }}{C}
$$

where $\gamma=0.015$.

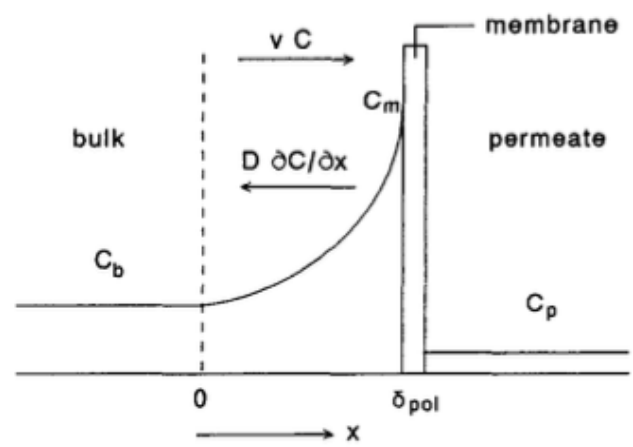

Fig. 4. Concentration polarisation showing convection, diffusion processes

\subsubsection{Osmotic pressure (OP) model}

In this model, the flux is explicitly related to the trans-membrane pressure, $\Delta P$, through an expression (5):

$$
J=\frac{\Delta P-\sigma_{0} \Delta \pi}{\mu R_{m}}
$$

where $\mu$ is the permeate viscosity, Pa.s; $R_{m}$ is the membrane resistance, $\mathrm{m}^{-1} ; \sigma_{0}$ is the osmotic reflection coefficient and $\Delta \pi$ is the osmotic pressure difference across the membrane.

However, when there is a complete rejection, the osmotic reflection coefficients approach one. Thus, for the cases of complete rejection which is a valid assumption for this study, the equation becomes

$$
J=\frac{\Delta P-\Delta \pi}{\mu R_{m}}
$$

Typically, the osmotic pressure is given by a virial equation of the form:

$$
\pi=\sum_{i=1}^{3} a_{i} C_{\text {lim }}^{i}
$$

By substituting the osmotic pressure expression:

$$
J=\frac{\Delta P-\sum_{i=1}^{3} a_{i} C_{\text {lim }}^{i}}{\mu R_{m}}
$$

\subsubsection{Pore blocking models}

The instantaneous filtration rate $J$ is proportional to the number of open pores and the flow through each pore by Hagen-Poiseuille law described as Eq. (9):

$$
J=\frac{d v}{d t}=\left(N^{\prime}-x v\right) \pi r_{0}^{2}\left(\frac{r_{0}^{2} p}{8 \mu L}\right)
$$

where $J$ is the instantaneous filtration rate at any filtration time $t, \mathrm{~s} ; v$ is the cumulative volume of filtrate collected per unit of membrane area, $\mathrm{m}^{3} / \mathrm{m}^{2} ; N^{\prime}$ is the number of pores per unit of membrane area; $x$ is the number of particles per unit of filtrate volume $v$, and $r_{0}{ }^{2}$ is the effective pore radius at the start of filtration, $\mathrm{m}^{2}$.

For constant pressure filtration, characteristic forms can be represented by Eq. (10) with two constants $K$ and $n$, which depend on the filtration mode:

$$
\frac{d^{2} t}{d v^{2}}=K\left(\frac{d t}{d v}\right)^{n}
$$

where the blocking index $n$ is a dimensionless filtration constant that characterises the mode of the fouling model involved, $n=2,1.5,1,0$ for complete pore blocking, standard blocking, intermediate blocking, and cake filtration, respectively; $K$ is the resistance coefficient depending on the system, the filtration medium, and the conditions of filtration. The derived equations for $K$ and filtration equations in terms of flux, volume, are presented by Iritani et al. [21].

The plugging constant of complete blocking law $\left(K_{b}\right)$ is defined by Eq. (11):

$$
K_{b}=\frac{x \pi r_{0}^{4} p_{0}}{8 \mu L}
$$

where $p_{0}$ is the applied pressure (transmembrane pressure) at the onset of filtration.

The plugging constant of standard blocking law $\left(K_{s}\right)$ is denoted by Eq. (12):

$$
K_{s}=\frac{2 C}{N^{\prime} L \pi\left(1-\varepsilon_{p}\right) r_{0}^{2}}
$$

The plugging constant of intermediate blocking law $\left(K_{i}\right)$, typically calculated empirically, is denoted by Eq. (13):

$$
J=\frac{d v}{d t}=N^{\prime} \exp \left(K_{i} v\right) \pi r_{0}^{2}\left(\frac{r_{0}^{2} p}{8 \mu L}\right)
$$

The Ruth filtration constant of cake filtration $\left(K_{v}\right)$ is denoted by Eq. (14):

$$
K_{v}=\frac{2 p(1-m s)}{\mu \alpha_{a v} \rho s}
$$




\subsection{Performance Prediction of Membranes}

In ultrafiltration both the osmotic pressure model and the gel-polarization model incorporate the phenomenon of concentration polarization. Based upon the film theory the polarization layer formation can be described by Eq. (15) considering a diffusion coefficient $D$ as a constant:

$$
\frac{\partial C}{\partial t}=-J \frac{\partial C}{\partial x}+D \frac{\partial^{2} C}{\partial x^{2}}
$$

Initial and boundary conditions:

$$
\begin{gathered}
t=0 ; 0 \leq x \leq \delta ; C=C_{b} \\
t>0 ; x=0 ; C=C_{b} \\
t>0 ; x=\delta ; J C_{\lim }=D\left(\frac{\partial C}{\partial x}\right)_{x=\delta}+J C_{p}
\end{gathered}
$$

\subsection{Back Flushing Simulation}

A resistance-in-series approach proposed by Gehlert, Chellam [23, 24] was used to describe a mass transfer for both forward filtration and back flushing. Closed form solution of flux in terms of the specific cake resistance and compressibility if the applied transmembrane pressure is constant with time can be expressed as Eq. (17):

$$
\frac{t}{V}=\frac{\mu R_{m}}{A_{m} \Delta P}+\frac{\mu \alpha \rho \phi_{0} V}{2 A_{m}^{2} \Delta P}
$$

\subsection{Cost Estimation}

Energy consumption for the pump in a pressuredriven membrane process was estimated using Eq. (18):

$$
E=\frac{Q_{0} P_{0}}{1259 \cdot 2 \eta \eta_{m}}
$$

where $E$ is the energy, $\mathrm{kW} ; Q_{0}$ is the feed flow rate, $\mathrm{m}^{3} / \mathrm{s}$; $P_{0}$ is the feed pressure, $\mathrm{Pa} ; \eta$ and $\eta_{m}$ are pump and motor efficiencies, respectively [25].

\section{Results and Discussion}

\subsection{Membrane Characterization}

\subsubsection{SEM study}

Fig. 5 reveals the surface and cross-sectional morphologies of 15\% PVDF membrane (Figs. 5a, 5b), synthesized UF membranes M-1 (Figs. 5c, 5d) and M-3 (Figs. 5e, 5f). The surface morphologies of the PVDF membranes show the presence of visible micropores, which were distributed uniformly across the surface without any agglomerations. The approximate pore size determined from the SEM picture was around 0.5 microns. The crosssectional view of the membrane shows the formation of two different layers, in which the top layer represents an ultra-porous PVDF layer, whereas the lower layer represents the nonwoven polyester fabric support with an adequate penetration of the PVDF layer (Figs. 5b, 5d, 5f). Neither any agglomerations nor cluster formations were observed in the multilayered polymer materials.

\subsubsection{FTIR Study}

Fig. 6 represents the FTIR spectra of hydrophilized PVDF membrane. FTIR spectra showed characteristic bands which appeared at $875 \mathrm{~cm}^{-1}\left(\mathrm{CF}_{2}\right), 1078 \mathrm{~cm}^{-1}$ (CC) and $1175 \mathrm{~cm}^{-1}$ (CC) similar to the bands observed for VDF containing mainly $\alpha$-phase while peaks at $839 \mathrm{~cm}^{-1}$ $\left(\mathrm{CH}_{2}\right)$, and $140 \mathrm{~cm}^{-1}\left(\mathrm{CH}_{2}\right)$ could be attributed to $\beta$-phase [16].

All the spectra from the modified membranes also exhibit a stretching vibration at $1723 \mathrm{~cm}^{-1}$ that was caused by the strengthening of carbon-oxygen double bonds in a glutaraldehyde cross-linking. The broad peak at 3300 $3350 \mathrm{~cm}^{-1}$ in the membrane was assigned to asymmetric vibration of hydroxyl $(-\mathrm{OH})$ groups introduced by the PVA and acetal formation as represented by the reactions in Fig. 2. Table 2 describes the significance of various

\begin{tabular}{|c|c|}
\hline Absorption peak & Significance \\
\hline 1723 & $\mathrm{C}=\mathrm{O}$ of $\mathrm{PVA}-\mathrm{GA}$ \\
\hline 1441 & $\mathrm{CH}_{2}$ scissoring \\
\hline 1078 & $\mathrm{C}-\mathrm{C}$ stretching vibration of PVA \\
\hline 3584 & $\mathrm{O}-\mathrm{H}$ stretching vibration of PVA \\
\hline $3330-3350$ & $\begin{array}{l}\text { O-H stretching peak should decrease as compared to pure PVA because of the acetal formation and the } \\
\text { diminution in the number of OH group }\end{array}$ \\
\hline $1000-1140$ & $\mathrm{C}-\mathrm{O}$ and the acetal ring $(\mathrm{C}-\mathrm{O}-\mathrm{C})$ bands formed by the glutaraldehyde cross-linking reaction with PVA \\
\hline $1400,1175,875$ & Characteristic peaks of PVDF \\
\hline
\end{tabular}
functional groups in the IR spectra observed in consistence with the PVDF membranes analyzed by various authors $[9,17-19]$.

Table 2

The significance of various functional groups in IR spectra 

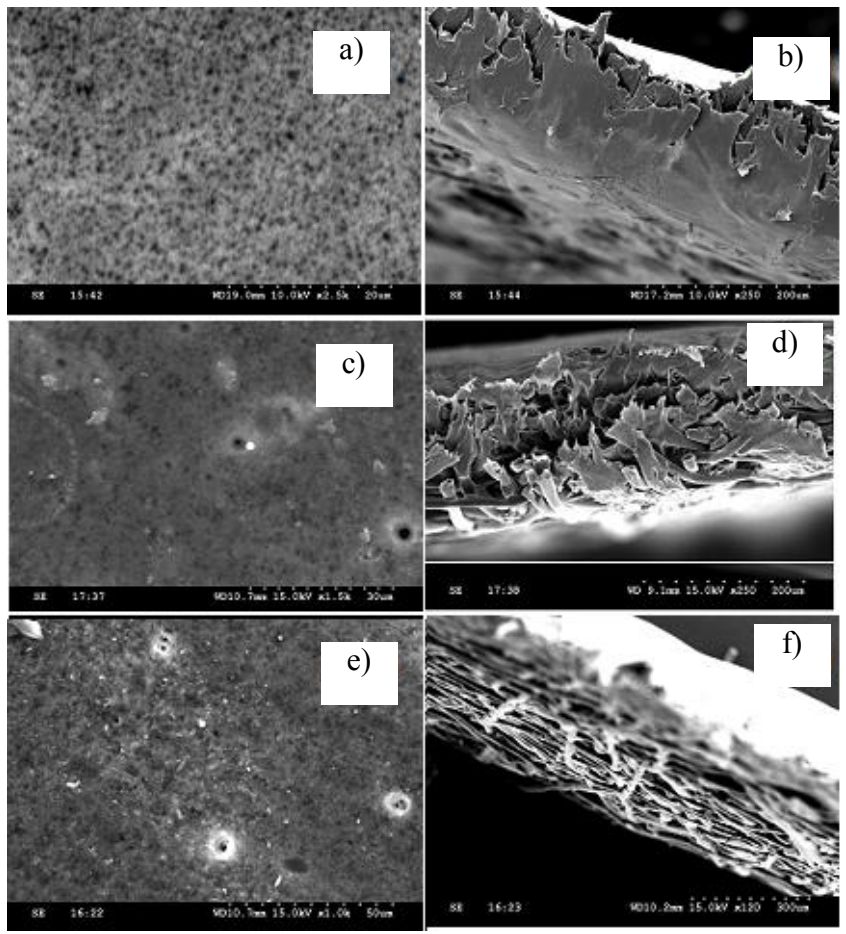

Fig. 5. Surface and cross-sectional views of membranes

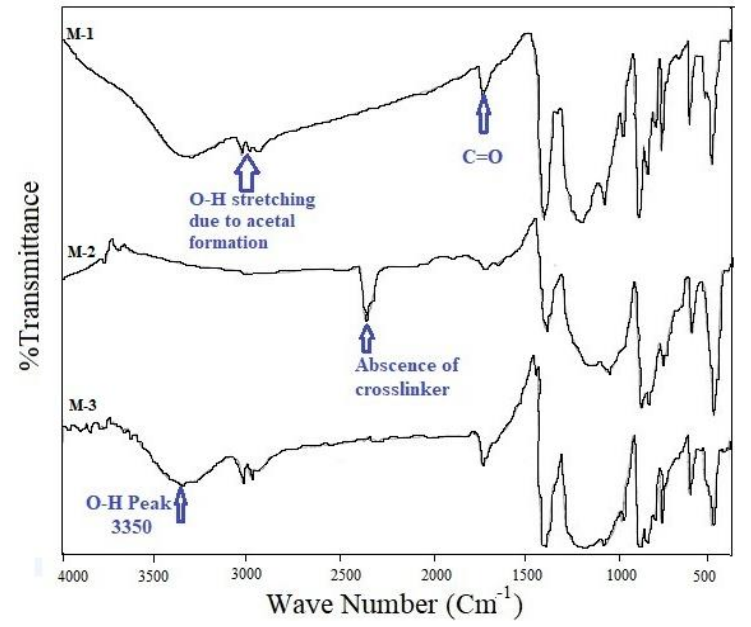

Fig. 6. FTIR spectra of the synthesized membranes
In Fig. 6 the absence of absorption peak at $2360.6 \mathrm{~cm}^{-1}$ in the spectra of M-1 and M-3 membranes and one strong vibration peak for $\mathrm{M}-2$ was attributed to the presence of the cross-linker. The reverse phenomenon was observed for peaks 976.21 and $975.92 \mathrm{~cm}^{-1}$. Additional absorption peaks at 3584, 3775.52, 1452.95 and $975.92 \mathrm{~cm}^{-1}$ in the spectra of M-3 were attributed to the stretching of $\mathrm{OH}$ groups and hydrophilicity.

\subsection{ANOVA Analysis}

Synthesized membranes were studied for a flux and turbidity removal for different operating conditions. Initially, the experimental design was used to organize a set of experiments to understand the effects of preparation conditions on the properties (i.e., a cross-linking agent composition in the membrane) used in the flux studies. The factors chosen were filtration time (parameter $\mathrm{A}, 10$ $60 \mathrm{~min}$ ), operating pressure (parameter $\mathrm{B}, 0.1-0.5 \mathrm{MPa}$ ), and cross-linker percentage in the membrane composition (parameter C, 0-2\%). Eight experiments were performed, and the results were analyzed using spreadsheet calculations.

Table 3 shows the results to evaluate the effect of these parameters. It is evident from Table 3 that the crosslinker has the higher impact on the flux than other operating parameters and the cross-linking during the membrane synthesis has more influence than the operating conditions in the UF process.

\subsection{Effect of Pressure}

Experiments were conducted with three synthesized membranes (M-1, M-2 and M-3) for the surface water with $230 \mathrm{FAU}$ of turbidity within a pressure range of $0.1-$ $0.5 \mathrm{MPa}$. Fig. 7 shows the variation of flux with different feed pressure. It was found that all three membranes have shown a linear trend as expected. Uncross-linked PVA/PVDF blend membrane (M-2) resulted in a maximum water flux, $3561 / \mathrm{m}^{2} \cdot \mathrm{h}$ at $0.5 \mathrm{MPa}$ pressure compared to M-1 and M-3. However, after cross-linking the membrane flux drastically reduced to $4-12 \mathrm{l} / \mathrm{m}^{2} \cdot \mathrm{h}$ due to the formation of acetal group reducing the membrane pore size [19]. Blending with additional PVA enhance hydrophilic nature of the matrix resulted in the higher water flux $\left(206 \mathrm{l} / \mathrm{m}^{2} \cdot \mathrm{h}\right)$ without compromising turbidity rejection.

Table 3

ANOVA data

\begin{tabular}{|c|c|c|c|c|c|}
\hline Source & Degree of freedom & Sum of squares & Variance & $F$-ratio & $p$-value \\
\hline A & 1 & 8571.33 & 8571.33 & 8.60 & 0.2092 \\
\hline B & 1 & 983.90 & 983.90 & 0.99 & 0.5016 \\
\hline C & 1 & 86000.49 & 86000.49 & 86.31 & 0.0683 \\
\hline $\mathrm{A}^{*} \mathrm{~B}$ & 1 & 986.57 & 986.57 & 0.99 & 0.5016 \\
\hline $\mathrm{A}^{*} \mathrm{C}$ & 1 & 8718.60 & 8718.60 & 8.75 & 0.2075 \\
\hline $\mathrm{B}$ C & 1 & 481.12 & 481.12 & 0.48 & 0.6143 \\
\hline Error & 1 & 996.36 & 996.36 & & \\
\hline Total & 7 & 106738 & & & \\
\hline
\end{tabular}

Note: * A - filtration time; $\mathrm{B}$ - pressure; $\mathrm{C}$ - cross-linker \% 


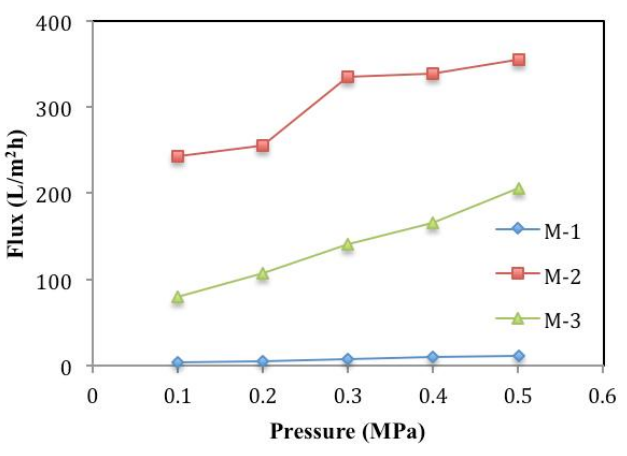

Fig. 7. Variation of flux with pressure

\subsection{Effect of Filtration Time}

Experiments were conducted at five different pressures and collected permeate at regular intervals up to 120 min duration. Fig. 8 shows the variation of membrane flux with operational time for three synthesized membranes (M-1, M-2 and M-3). It was found that the flux was decreasing for all the membranes with operational time as expected. Cross-linked membrane M-3 has shown a linear trend in the flux decreasing from 244 to $183 \mathrm{l} /\left(\mathrm{m}^{2} \cdot \mathrm{h}\right)$ due to the cake formation on the membrane surface which offered the higher resistance.

\subsection{Modeling and Simulation}

\subsubsection{Limiting flux model with the constant mass transfer coefficient}

Experimental results were fitted to the limiting flux model (Eq. 3) which assumes a constant mass transfer coefficient for each membrane, in terms of total dissolved solids (TDS) expressed in units of mg/l. Fig. 9 show the variation of flux with $\ln C$ for three synthesized membranes at different pressures. Mass transfer coefficient $(k)$ and the limiting concentration $\left(C_{\mathrm{lim}}\right)$ of TDS $(\mathrm{mg} / \mathrm{l})$ were calculated from the slope and intercept for each membrane and are listed in Table 4 along with the coefficient of determination $\left(R^{2}\right)$ values of the linear fit. Poor fit with the values of $R^{2}$ in the range of $0.42-0.87$ indicates that the limiting flux model with the constant mass transfer coefficient is not a suitable model for this study.
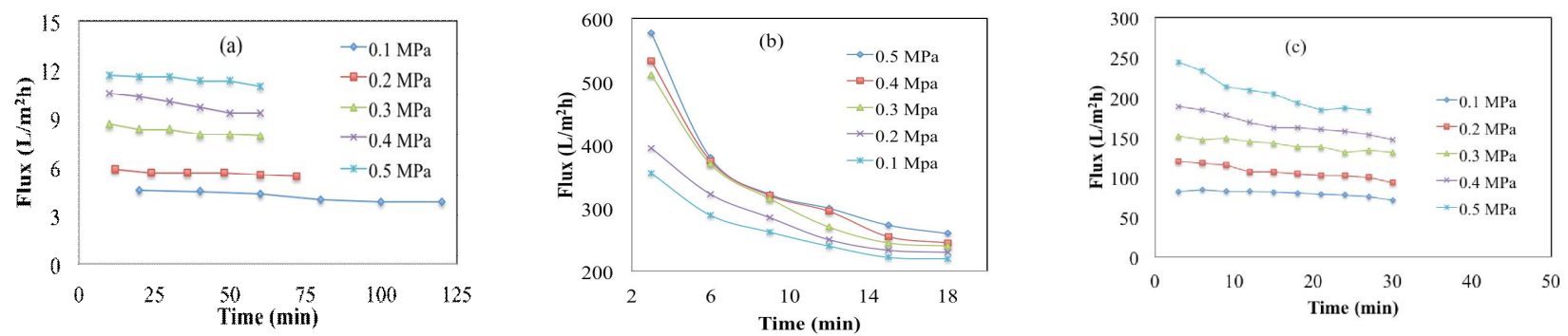

Fig. 8. Variation of flux with operational time at different pressures for three synthesized membranes: M-1 (a); M-2 (b) and M-3 (c)

Table 4

Limiting flux model parameters for the synthesized membranes

\begin{tabular}{|c|c|c|c|c|c|c|c|}
\hline \multirow{2}{*}{ Membrane } & \multirow{2}{*}{$\begin{array}{c}\text { \% Rejection } \\
\text { (TDS) }\end{array}$} & \multicolumn{3}{|c|}{$\begin{array}{c}\text { Limiting flux model with a constant mass } \\
\text { transfer coefficient }\end{array}$} & \multicolumn{3}{c|}{$\begin{array}{c}\text { Limiting flux model with a viscosity } \\
\text { dependent mass transfer coefficient }\end{array}$} \\
\cline { 3 - 8 } & & $k \cdot 10^{6}, \mathrm{~m} / \mathrm{s}$ & $C_{\text {lim }}, \mathrm{g} / \mathrm{l}$ & $R^{2}$ value & $K_{0} \cdot 10^{6}, \mathrm{~m} / \mathrm{s}$ & $C_{\text {lim }}, \mathrm{g} / 1$ & $R^{2}$ value \\
\hline M-1 & $98-99.2$ & $0.9-2.5$ & $1-264$ & $0.45-0.86$ & $1.3-4.5$ & $1.1-2.9$ & $0.76-0.92$ \\
\hline M-2 & $98.5-99.8$ & $43-221$ & $434-1921$ & $0.42-0.83$ & $61-289$ & $4.5-12.6$ & $0.8-0.85$ \\
\hline M-3 & $98.4-99.3$ & $5.6-73$ & $615-3230$ & $0.71-0.87$ & $32-419$ & $6.5-13.5$ & $0.75-0.88$ \\
\hline
\end{tabular}

Note: parameter values were provided for the pressure range of $0.1-0.5 \mathrm{Mpa}$
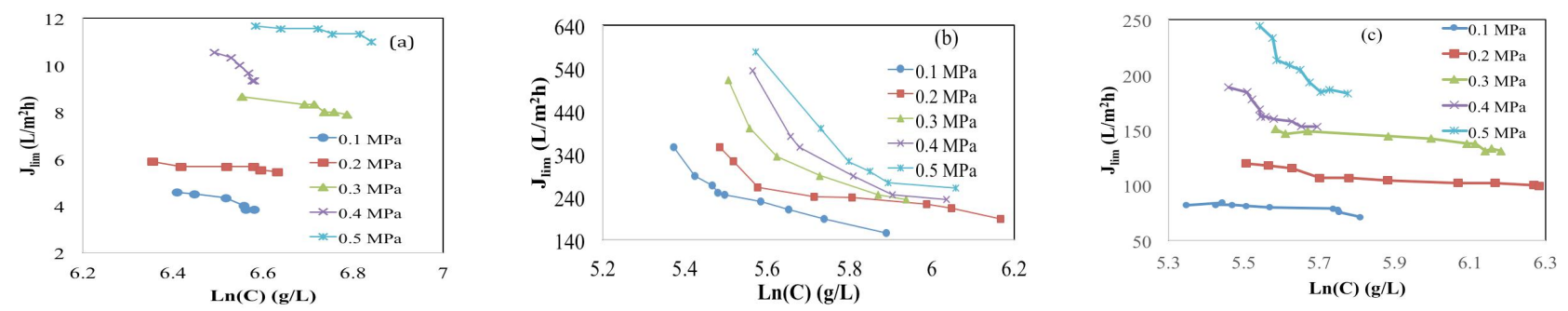

Fig. 9. Variation of limiting flux with $\ln C$ of total dissolved solids at different operating pressures 


\subsubsection{Limiting flux model with the viscosity dependent mass transfer coefficient}

Experimental results were fitted to the model Eq. (4) using the MATLAB R2016a curve-fitting toolbox and calculated the mass transfer coefficient $\left(k_{0}\right)$ and limiting concentration $\left(C_{\mathrm{lim}}\right)$ for all three synthesized membranes and the same were listed in Table 4. Though, the fit was found to have slightly improved coefficient of determination $\left(R^{2}\right)$ values as compared to the limiting flux model with the constant mass transfer coefficient, the values were observed in the range of $0.75-0.92$, hence it was evident that this was not a suitable model.

\subsubsection{Osmotic pressure (OP) model}

Flux variation with the applied trans-membrane pressure was plotted and was shown in Fig. 7. Experimental results were fitted to the model Eq. (8) to calculate the membrane resistance $\left(R_{m}\right)$ and virial coefficients $\left(a_{i}\right)$ from the slope and intercepts of the plot, respectively. Table 5 shows the slopes and intercepts for Eq. (8) and virial coefficients estimated and found to be $6.82 \cdot 10^{3},(-9.46) \cdot 10^{-6}$ and $559.56 \cdot 10^{-12}$, respectively. The experimental findings were following this model with a significant accuracy and the coefficient of determination $\left(R^{2}\right)$ values for cross-linked membranes were found to be in the range of $0.96-0.99$. The accumulation of solute molecules at the membrane surface created an osmotic back pressure that must be overcome by the applied trans- membrane pressure. In absence of cross-linker, this model may not be a good fit.

\subsubsection{Pore blocking models}

Experimental data were fitted to the pore blocking models, namely complete, standard, intermediate blocking and the cake filtration by plotting the graphs (complete pore blocking model: $J v s . v$; standard blocking model: $t v s . t / v$; intermediate blocking model: $t v s$. $1 / J$; cake filtration model: $v v s . t / v)$ proposed by Iritani [21]. The results are listed in Table 6. Plugging constants were calculated from the slopes of the plots according to Eqs. (9)-(11). Initial flux $\left(J_{0}\right)$ values calculated from the intercepts of the plots and found from the cake filtration model were in the range of $198-400$ and $45-138 \mathrm{l} / \mathrm{m}^{2} \cdot \mathrm{h}$ for $\mathrm{M}-2$ and M-3 membranes, respectively. These estimated flux values were found to be in good agreement with the experimental findings. Complete blocking and intermediate blocking models predicted abnormally high initial fluxes as compared to the experimental data. Standard pore blocking law predicted the initial fluxes in the range of $200-328$ and $45-134 \mathrm{l} / \mathrm{m}^{2} \cdot \mathrm{h}$ for M-2 and M-3 membranes, respectively. The coefficients $R^{2}$ were found to be satisfactory for both cake filtration and the standard blocking models; they were in the range of $0.92-0.99$. These estimates reinforced the observation from the osmotic pressure model that the filtration was more controlled than the cake/gel layer formation for the studied system.

Table 5

Osmatic pressure model parameters for the synthesized membranes

\begin{tabular}{|c|c|c|c|}
\hline Membrane & Slope $10^{6}$ & Intercept $10^{6}, \frac{\sum_{i=1}^{3} \text { lim }}{\mu R_{m}}$ & $R^{2}$ value \\
\hline M-1 & 1.9613 & 1.736 & 0.9616 \\
\hline M-2 & 30.867 & 213.1 & 0.8718 \\
\hline M-3 & 31.186 & 46.219 & 0.9955 \\
\hline
\end{tabular}

Table 6

Pore blocking model parameters

\begin{tabular}{|c|c|c|c|c|c|c|c|c|c|c|c|c|}
\hline \multirow[b]{2}{*}{ 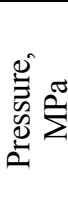 } & \multicolumn{3}{|c|}{ Complete pore blocking model } & \multicolumn{3}{|c|}{ Intermediate blocking model } & \multicolumn{3}{|c|}{ Standard blocking model } & \multicolumn{3}{|c|}{ Cake filtration model } \\
\hline & $\begin{array}{l}\frac{0}{0} \\
\frac{0}{0} \\
\vdots \\
\vdots\end{array}$ & 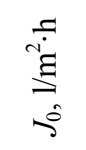 & 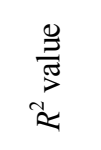 & $\begin{array}{l}\frac{0}{0} \\
\frac{0}{0} \\
0 \\
i=0\end{array}$ & 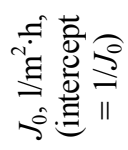 & 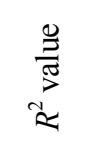 & 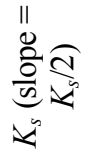 & 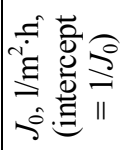 & 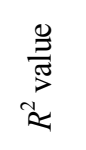 & 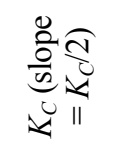 & 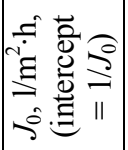 & $\begin{array}{l}\frac{0}{\pi} \\
\frac{\pi}{\pi} \\
\text { है }\end{array}$ \\
\hline \multicolumn{13}{|c|}{ M-2 membrane } \\
\hline 0.1 & 0.052 & 358.2 & 0.934 & $5 \cdot 10^{-4}$ & 450 & 0.901 & $8 \cdot 10^{-4}$ & 200 & 0.97 & $1.8 \cdot 10^{-5}$ & 198 & 0.984 \\
\hline 0.2 & 0.062 & 385.2 & 0.915 & $4 \cdot 10^{-4}$ & 400 & 0.951 & $6 \cdot 10^{-4}$ & 200 & 0.986 & $2 \cdot 10^{-5}$ & 211.7 & 0.993 \\
\hline 0.3 & 0.1 & 547.2 & 0.95 & $6 \cdot 10^{-4}$ & 720 & 0.983 & $8 \cdot 10^{-4}$ & 299 & 0.996 & $1.8 \cdot 10^{-5}$ & 327.2 & 0.991 \\
\hline 0.4 & 0.12 & 604.8 & 0.934 & $5 \cdot 10^{-4}$ & 600 & 0.967 & $1 \cdot 10^{-3}$ & 327 & 0.991 & $2 \cdot 10^{-5}$ & 360 & 0.994 \\
\hline 0.5 & 0.106 & 594 & 0.841 & $5 \cdot 10^{-4}$ & 600 & 0.93 & $1 \cdot 10^{-3}$ & 328 & 0.973 & $2 \cdot 10^{-5}$ & 400 & 0.994 \\
\hline \multicolumn{13}{|c|}{ M-3 membrane } \\
\hline 0.1 & 0.009 & 86.9 & 0.962 & $3 \cdot 10^{-4}$ & 88.6 & 0.877 & $2 \cdot 10^{-4}$ & 45.7 & 0.954 & $2 \cdot 10^{-5}$ & 45.54 & 0.939 \\
\hline 0.2 & 0.01 & 124.9 & 0.922 & $3 \cdot 10^{-4}$ & 123.3 & 0.93 & $6 \cdot 10^{-4}$ & 65.8 & 0.99 & $2 \cdot 10^{-5}$ & 65.5 & 0.98 \\
\hline 0.3 & 0.009 & 153 & 0.937 & $1 \cdot 10^{-4}$ & 154.5 & 0.937 & $2 \cdot 10^{-4}$ & 82.2 & 0.98 & $1 \cdot 10^{-5}$ & 83.7 & 0.975 \\
\hline \begin{tabular}{|l|}
0.4 \\
\end{tabular} & 0.017 & 192 & 0.954 & $2 \cdot 10^{-4}$ & 192.2 & 0.96 & $4 \cdot 10^{-4}$ & 103.4 & 0.99 & $1.6 \cdot 10^{-6}$ & 105.9 & 0.992 \\
\hline 0.5 & 0.025 & 252 & 0.925 & $2 \cdot 10^{-4}$ & 248.3 & 0.945 & $4 \cdot 10^{-4}$ & 134.3 & 0.989 & $1.6 \cdot 10^{-6}$ & 138.4 & 0.974 \\
\hline
\end{tabular}




\subsection{Performance Prediction of Membranes}

Using the estimated virial coefficients $\left(a_{i}\right)$ and the membrane resistance $(\mathrm{Rm})$ from the osmotic pressure model for the synthesized membranes, the membrane scale-up and performance can be predicted. If the solute molecules were nearly completely rejected, the osmotic pressure at the permeate side can be neglected which was a valid assumption for this work as a turbidity removal was consistently above $98 \%$. MATLAB was used to solve Eq. (15) with the boundary conditions mentioned in Eq. (16) to understand the dynamic behavior of the membrane. The results are shown in Fig. 10. In this simulation, the thickness of the concentration polarisation layer was varied and the concentration profile from the membrane surface at different time steps was noted. The concentration polarization layer thickness was calculated and found to be $1.5 \cdot 10^{-4}, 9.5 \cdot 10^{-4}$, and $18.5 \cdot 10^{-4} \mathrm{~m}$ for membranes $\mathrm{M}-1, \mathrm{M}-2$, and $\mathrm{M}-3$, respectively. Limiting concentrations were found to be 237,408 and $409.8 \mathrm{~g} / \mathrm{l}$, respectively. These values were in good agreement with the simulation results of the limiting flux model.

\subsection{Back Flushing Simulation}

Model equations proposed by Gehlert [23] for studying the dynamic behavior of M-3 membrane at applied 0.5 MPa trans-membrane pressure were solved using MATLAB 2016a.The studied parameters, namely the permeate volume, cake mass accumulated per unit of membrane area and $\gamma$ (parameter which was a constant and explained the long-term permeate flux decline by an increase of the specific cake resistance) vary with time and are shown in Fig. 11. The membrane resistance $\left(R_{m}\right)$ values computed from osmotic pressure model at different pressures were used for this simulation. Other model parameters based on the physical properties along with the membrane resistance values are shown in Table 7. It was observed from the study that the cake thickness is increasing continuously with time and reached its maximum thickness with time; no change were observed after $97 \mathrm{~h}$. From the simulation study, a back flushing time of $97 \mathrm{~h}$ was proposed.

\subsection{Economic Estimation}

Table 8 provides the capital and operating costs of the UF process considered in this work for feed capacity of $1000 \mathrm{~m}^{3} /$ day considering 2 years of operation. Based on the experimental data, the M-3 membrane with $2.25 / 15 \%$ PVA/PVDF blend and glutaraldehyde crosslinking was considered for the economic estimation.

For an operating pressure of $0.5 \mathrm{MPa}$, the average flux from the experimental data shows $205 \mathrm{l} / \mathrm{m}^{2} \cdot \mathrm{h}$, which implies that a total membrane area of $216 \mathrm{~m}^{2}$ was required for feed capacity of $44 \mathrm{~m}^{3} / \mathrm{h}$. The total area can be scaled up in the form of spiral wound membrane and distributed as 6 modules of 8 " diameter $\times 40$ " length each having $36 \mathrm{~m}^{2}$ of effective membrane area. Thus, the capital cost consisting of the membrane and its housing, pumps, instruments, and tanks are shown in Table 8. The total capital investment comes to US\$ 46,800 .
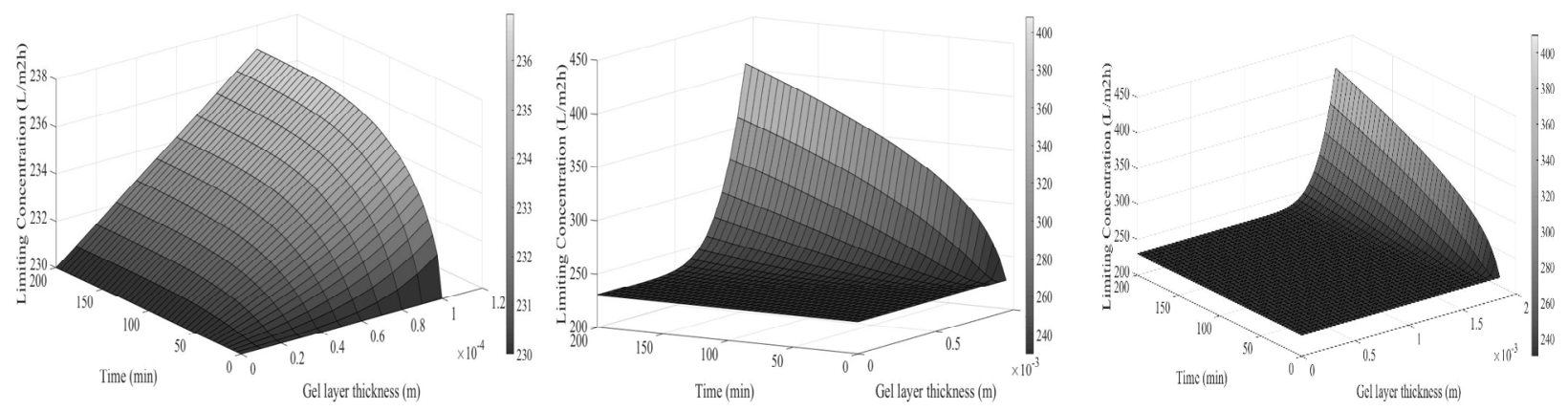

Fig. 10. Variation of concentration with time and gel layer thickness at the membrane wall

Model parameters for the M-3 membrane

\begin{tabular}{|c|c|c|}
\hline Parameter & Value & Unit \\
\hline$\alpha_{0}$ & $7.94 \cdot 10^{11}$ & $\mathrm{~m}^{-1}$ \\
\hline$n$ & 0.8544 & - \\
\hline TS & 4 & $\mathrm{~kg} / \mathrm{m}^{3}$ \\
\hline$k_{d m}$ & $1.256 \cdot 10^{-6}$ & $\mathrm{~s}^{-1}$ \\
\hline$R_{m}$ & $1.471 \cdot 10^{13}, 5.015 \cdot 10^{12}, 2.70 \cdot 10^{12}, 1.585 \cdot 10^{12}, 9.738 \cdot 10^{11}$ at $0.1,0.2,0.3,0.4$ and $0.5 \mathrm{MPa}$, & $\mathrm{m}$ \\
\hline
\end{tabular}



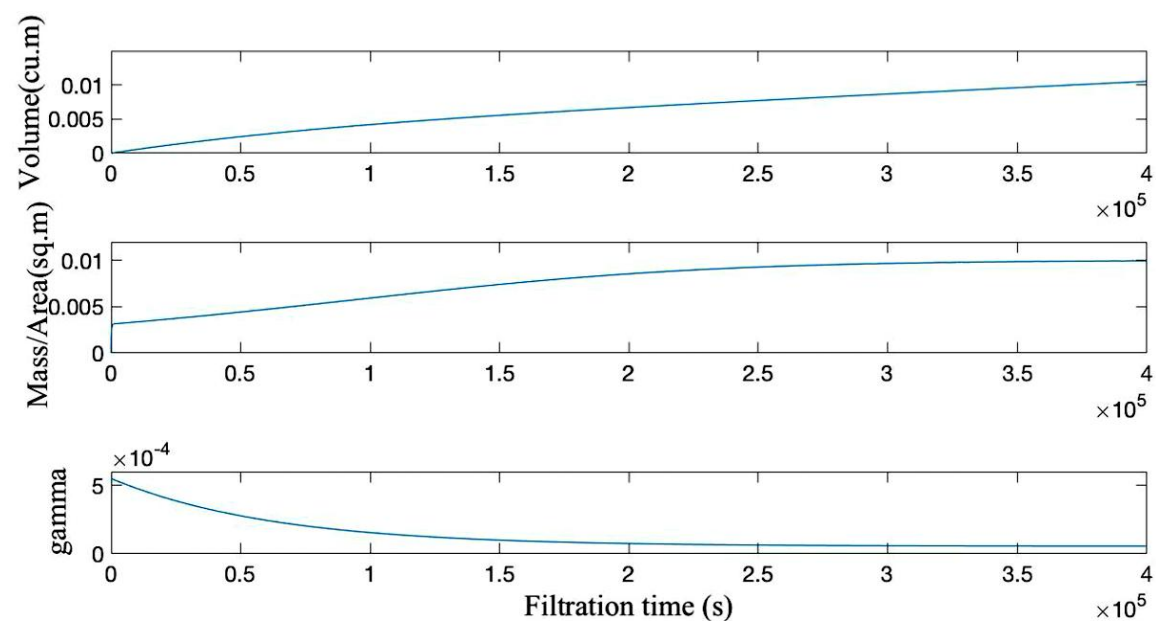

Fig. 11. Permeate volume, cake mass per membrane area and $\gamma$ variation with time

Table 8

Cost estimation for UF process

\begin{tabular}{|c|c|c|}
\hline Type of costs & Specification & Cost, US\$ \\
\hline \multirow{5}{*}{ Capital costs } & System Cost & 38,000 \\
\hline & Pump Costs & 1,100 \\
\hline & Costs for site preparation & 4,400 \\
\hline & Instrumentation & 3,300 \\
\hline & Total & 46,800 \\
\hline \multirow{6}{*}{ Operating costs } & Pumping & 8870 \\
\hline & Membrane Replacement & 2200 \\
\hline & Depreciation & 4270 \\
\hline & Maintenance (Chemicals, Spares, etc.) & 275 \\
\hline & Total & 15,615 \\
\hline & Cost, US $\$ \mathrm{~m}^{3}$ & 0.03 \\
\hline
\end{tabular}

Energy consumption of high-pressure pump and membrane replacement cost were the major contributors to the operating costs. The energy consumption for the pump was calculated using Eq. (18). Operating pressure of $0.5 \mathrm{MPa}$ and the efficiencies of 0.6 and 0.7 were assumed for the pump and motor [26]. The operating cost consists of power consumption, membrane maintenance, membrane replacement and depreciation for a 2-year operating period comes to US\$ 15,615 indicating an expenditure of US $\$ 0.03 / \mathrm{m}^{3}$ of the feed processed.

\section{Conclusions}

Indigenous hydrophilized polyvinylidene fluoride membrane was prepared with PVDF/polyvinyl alcohol blend and further cross-linked with glutaraldehyde which has shown a significant flux improvement as compared to the reported membranes and with retaining the high degree of hydrophilicity and low fouling characteristics. From the IR spectra of the synthesized membranes the $\mathrm{O}-\mathrm{H}$ stretching and the acetal formation were observed which were attributed to the polyvinyl alcohol blending and glutaraldehyde cross-linking. SEM images of the synthesized membranes revealed that highly cross-linked membranes had a higher surface coverage and much smaller pores, higher hydrophilicity, and higher flux, the hydrophilicity increased in the row $\mathrm{M}-3>\mathrm{M}-1>\mathrm{M}-2$. PVDF/PVA blend membrane resulted in a reasonable process flux of $2051 / \mathrm{m}^{2} \cdot \mathrm{h}$ at $0.5 \mathrm{MPa}$. Effect of applied trans-membrane pressure and operational time on the flux was studied and the experimental findings were used to fit different models and estimate the model parameters such as the mass transfer coefficient, limiting concentration, virial coefficients and membrane resistance. Also, it was found that limiting flux models were not appropriate for the synthesized membranes and the concentration polarization effect was reduced in the hydrophilized membranes. Osmotic pressure model was in agreement with the experimental findings. Back flushing requirement was simulated and found to be $97 \mathrm{~h}$ per each cycle. Timedependent behavior of the membrane was predicted with a theoretical model and the predictions were in the good agreement with the experimental observations. Costs estimation US\$ 46,800 was shown as the capital costs and US\$ 15,615 as operating costs for $1000 \mathrm{~m}^{3} / \mathrm{h}$ capacity. 


\section{Acknowledgments}

One of the authors would like to thank for the support extended by the Chemical Engineering Division, CSIR-Indian Institute of Chemical Technology, Hyderabad, India for the facilities and the help. Also, acknowledge National Project Implementation Unit (NPIU) and State Project Facilitation Unit (SPFU), Telangana, India for the financial support through TEQIP-II.

\section{References}

[1] Brehant A., Bonnelye V., Perez M.: Desalination, 2002, 144, 353. https://doi.org/10.1016/S0011-9164(02)00343-0 [2] Wilf M., Schierach M.: Desalination, 2001, 135, 61. https://doi.org/10.1016/S0011-9164(01)00139-4

[3] Pathak T., Chung K.: J. Ind. Eng. Chem., 2006, 12, 539.

[4] Hashim N., Liu F., Li K.: J. Membrane Sci., 2009, 345, 134. https://doi.org/10.1016/j.memsci.2009.08.032

[5] Meng X., Zhao L., Wang L. et al.: Water Sci. Technol., 2012, 66, 2074. https://doi.org/10.2166/wst.2012.380

[6] Liu F., Hashim N., Liu Y. et al.: J. Membrane Sci., 2011, 375, 1. https://doi.org/10.1016/j.memsci.2011.03.014

[7] Mailvaganam M., Goodboy K., Bai J.: US Pat. 6024872, Publ. Feb. 15, 2000.

[8] Rhim J.-W., Kim J.-S., Park C.-Y. et al.: Membrane J., 2013, 23, 312. http://membranejournal.or.kr/journalarticle.php?code=12316

[9] Li N., Xiao C., An S., Hu X.: Desalination, 2010, 250, 530. https://doi.org/10.1016/j.desal.2008.10.027

[10] Wang X., Chen C., Liu H., Ma J.: Water Res., 2008, 42, 4656. https://doi.org/10.1016/j.watres.2008.08.005

[11] Linares A., Nogales A., Rueda D., Ezquerra T.: J. Polym. Sci. B, 2007, 45, 1653. https://doi.org/10.1002/polb.21210

[12] Zhang Y., Li H. et al.: Desalination, 2006, 192, 214.

https://doi.org/10.1016/j.desal.2005.07.037

[13] Rajaeian B., Heitz A., Tade M., Liu S.: J. Membrane Sci., 2015, 485, 48. https://doi.org/10.1016/j.memsci.2015.03.009

[14] Li X., Chen Y., Hu X. et al.: J. Membrane Sci., 2014, 471, 118. https://doi.org/10.1016/j.memsci.2014.08.018

[15] Xu J., Ma C., Cao B. et al.: Proc. Safety Environ. Protect., 2016, 104B, 564, https://doi.org/10.1016/j.psep.2016.06.020

[16] Azmi R., Goh P., Ismail A. et al.: J. Food Eng., 2015, 166, 165. https://doi.org/10.1016/j.jfoodeng.2015.06.001

[17] dos Reis E., Campos F., Lage A. et al.: Mater. Res., 2006, 9, 185.

https://doi.org/10.1590/S1516-14392006000200014

[18] Madhumala M., Satyasri D., Sankarshana T., Sridhar S.: Ind.

Eng. Chem. Res. 2014, 53, 17770.

https://doi.org/10.1021/ie502566b

[19] Chowdari B., Kawamura J., Mizusaki J. (Eds.): Proceeding of the 13th Asian Conference on Solid State Ionics: Ionics for Sustainable World, Sendai Japan, 17-20 July 2012. World Scientific 2012.
[20] Bowen W., Jenner F.: Adv. Colloid Interface Sci., 1995, 56, 141. https://doi.org/10.1016/0001-8686(94)00232-2

[21] Iritani E.: Dry. Technol., 2013, 31, 146. https://doi.org/10.1080/07373937.2012.683123

[22] Foley G.: Membrane Filtration: A Problem Solving Approach with MATLAB. Cambridge University Press 2013, 88-103.

[23] Gehlert G., Abdulkadir M., Fuhrmann J., Hapke J.: J.

Membrane Sci., 2005, 248, 63.

https://doi.org/10.1016/j.memsci.2004.09.026

[24] Chellam S., Jacangelo J., Bonacquisti T.: Environ. Sci. Technol., 1998, 32, 75. https://doi.org/10.1021/es9610040

[25] Perry J.: Chemical Engineers' Handbook, $4^{\text {th }}$ edn. McGraw

Hill, New York 1963.

[26] McCabe W., Smith J., Harriott P.: Unit Operations of Chemical Engineering, $5^{\text {th }}$ edn. McGraw Hill, New York 1993.

[27] Bai H., Wang X., Zhou Y., Zhang L.: Prog. Nat. Sci. Mater. Int., 2012, 22, 250. https://doi.org/10.1016/j.pnsc.2012.04.011)

Received: July 16, 2018 / Revised: October 09, 2018 / Accepted: December 20, 2019

\section{СИНТЕЗ ТА ХАРАКТЕРИСТИКА ГІДРОФІЛІЗОВАНИХ \\ ПОЛІВІНІЛІДЕНФЛУОРИДНИХ МЕМБРАН ДЛЯ ОЧИЩЕННЯ ПИТНОЇ ВОДИ: ЕКСПЕРИМЕНТАЛЬНІ ДОСЛІДЖЕННЯ ТА МОДЕЛЮВАННЯ}

\begin{abstract}
Анотація. Проведено гідрофілізацію полівініліденфлуоридних мембран (ПВДФ) внаслідок змімування з полівініловим спиртом (ПВС), і подальшим зииванням із глутаральдегідом. Синтезовані мембрани досліджені в процесах очищення поверхневих вод. Для вивчення поверхневої $і$ поперечної морфології та міжмолекулярних взаємодій проведені дослідження мембран з використанням скануючої електронноі мікроскопї̈ та спектроскопії Фур'є. Вивчено вплив параметрів, а саме: тиску, часу та кониентрачії зииваючого агента на ефективність проиесу. Для прогнозування впливу кониентраиійної поляризаиії на ефективність розділення $i$ частоту зворотного промивання на основі експериментально встановлених даних граничного потоку, осмотичного тиску та моделі блокування пор знайдено відповідну теоретичну модель. Встановлено, що модель осмотичного тиску є придатною моделлю, а прогнозовані результати добре узгоджуються з експериментальними даними. Після перевірки моделі для синтезованоі мембрани, проведено симуляиію для прогнозування утворення осаду та визначено час зворотного промивання 97 год. Для підтвердження економічної доцільності розробленого процесу проведено оцінку вартості пілотної установки потужністю $1000 \mathrm{\mu}^{3} /$ дбу.
\end{abstract}

Ключові слова: гідрофілізований полівініліденфлуор, ультрафільтрачія, мутність, глутаральдегід, структурування, полівініловий спирт. 